\title{
Filsafat IImu Pendidikan Agama Kristen dan Praksisnya bagi Agama Kristen Masa Kini
}

\author{
Hasudungan Sidabutar \\ Institut Agama Kristen Negeri Kupang \\ hasudungan090584@gmail.com
}

\begin{abstract}
Philosophy is a method of thinking systematically and critically. In connection with Christian religious education, it must be studied systematically and critically as basis for knowledge so that it is parallel to other sciences that show real benefits for the development of humanity. The author will describe Christian Religious Education as a science praxis ontologically, epistemologically and axiologically. The method used in this research is systematic literature study approach. Ontologically Christian religious education must be a strong guide towards the journey of human life so that it is able to exist and exist both theologically and socially. Epistemology talks about knowledge. Epistemologically, the Bible and Jesus are the epistemological sources of Christian religious education. Axiology speaks of utility value. The axiological foundation of Christian Religious Education is a loving humanist inspired by Christian values. In other words, it axiology helps to humanize humans and free them from the alienation of their human role in life.
\end{abstract}

Keywords: philosophy, praxis, Christian Religious Education

Abstrak: Filsafat merupakan metode berfikir secara sistematis dan kritis. Sehubungan dengan pendidikan agama Kristen, maka ia harus dikaji secara sistematis dan kritis sebagai basis ilmu sehingga mampu sejajar dengan ilmu-ilmu lain yang menunjukkan kemanfaatan nyata bagi perkembangan kemanusiaan. Penulis akan menguraikan Pendidikan Agama Kristen sebagai praksis ilmu secara ontologis, epistemologis dan aksiologis. Metode yang digunakan dalam penelitian ini adalah pendekatan studi literatur. Secara ontologis pendidikan agama Kristen harus menjadi pedoman yang kuat kearah perjalanan hidup manusia supaya ia mampu ber-ada dan ber-eksistensi baik secara teologis maupun sosial. Epistemologi berbicara tentang pengetahuan. Secara epistemologis, Alkitab dan Yesus adalah sumber epistemologi pendidikan agama Kristen. Aksiologi berbicara tentang nilai kegunaan. Landasan aksiologis pendidikan agama Kristen adalah humanis yang penuh kasih yang dijiwai oleh nilai-nilai kristiani. Dengan kata lain aksiologis dapat membantu memanusiakan manusia dan membebaskannya dari keterasingan fungsi kemanusiaannya dalam kehidupan.

Kata kunci: filsafat, praksis, Pendidikan Agama Kristen

$\begin{array}{llll}\text { Article History : } & \text { Received: 29-10-2020 Accepted: 22-12-2020 }\end{array}$




\section{Pendahuluan}

Pazmino menjelaskan bahwa pendidikan merupakan hasil dari akar filosofisnya ${ }^{1}$ dan karenanya pendidikan agama Kristen (PAK) seharusnya bukan hanya sekedar mengajar sebuah keyakinan yang asal diyakini, melainkan PAK harus memiliki landasan filosofis mengapa ia diyakini. Agama Kristen juga bukan hanya agama belaka namun agama Kristen juga merupakan suatu ilmu dan karena ia merupakan bagian dari ilmu, maka ia disebut PAK. Sebagai ilmu, maka seharusnya PAK merupakan wadah yang edukatif kepada para pemeluknya dengan berbagai nilai yang terkandung di dalamnya sehingga membentuk umat kristiani menjadi manusia yang seutuhnya bukan hanya sekedar makhluk penyembah yang buta, seperti ungkapan sinisme Nietzsche terhadap kaum pemeluk agama bahwa Tuhan sudah mati. ${ }^{2}$ Dengan kematian Tuhan, Nietzsche sang filsuf atheis seperti menguatkan bahwa hanya dengan kematian Tuhanlah peradaban manusia akan dapat mencapai tingkatan yang lebih tinggi. ${ }^{3}$ Pernyataan ini merupakan bentuk ketidakpercayaan dan kekesalannya pada institusi gereja. Dengan ekstrim Nietzsche menghadapkan manusia pada dua pilihan yaitu Tuhan yang hidup atau manusia yang hidup. Apabila Tuhan yang hidup berarti manusia yang mati, demikian sebaliknya. Jika manusia hidup berdampingan dengan Tuhan maka tidak ada garansi dunia dapat dimengerti, serta lenyap juga jaminan bagi identitas manusia. Kedua hal itu tidak mungkin berada secara bersama-sama.

Agama Kristen melalui usaha ilmu pendidikan (para pendidik agama Kristen), harus mengeluarkan dirinya agar tidak menjadi "jimat" yang memberi keuntungankeuntungan materi kepada kaum penganutnya dimana pengorbanan-pengorbanan umat menunjukkan harapan akan harta yang tersembunyi (sorga) seperti kritik Marthin Luther terhadap kedikdayaan Gereja Katolik terhadap penjualan surat hutang dosa (indulgensia). Sebagai ilmu, PAK harus menghindarkan diri dari ajaran mistisisme yang membangkitkan ketakutan-ketakutan "rohani" antara dualisme baik dan buruk secara determinisme, sebab ketakutan dapat membuat manusia secara membabi buta percaya pada apapun dan tidak jarang hal ini menjadi lahan bisnis dimana bisnis mereka tidak dengan orang melainkan dengan manipulasi keyakinan manusia. Untuk itu orang Kristen melalui filsafat ilmu pendidikan membutuhkan suatu fondasi yang kuat untuk menguji kepastian kebenaran, pandangan, pemahaman dan pengajaran yang berkembang ditengah masyarakat sebagai realitas sosial dimana ia berada secara eksistensial. Sebab kritik Marx atas agama dimana agama adalah candu perlu mendapat perhatian serius. Tesis Marx tersebut muncul akibat pengalaman secara empiris dimana hakikat manusia yang beragama yang percaya kepada Tuhan tidak muncul dalam realitas sosial masyarakat. PAK harus memiliki basis keilmuan secara filosofis dan

1 Pazmino, Fondasi Pendidikan Kristen (Jakarta: BPK Gunung Mulia, 2016), 110.

2 Friederich Wilhelm Nietzsche (1844-1900) Requim aeternam deo! yang berarti semoga Tuhan beristirahat dalam keadaan damai.

${ }^{3}$ Karen Amrstrong, A History of God (New York: Alfred A Knopf Inc, 1993), 356. 
konkret agar Agama Kristen tidak menjadi candu dan terjebak dalam konsep-konsep doktrinal mistik, dan ini merupakan persoalan serius yang harus segera dituntaskan oleh para pendidik Kristen masa kini.

Secara praksis pendidikan tidak hanya sekedar diajarkan namun harus memiliki arah dan tujuan yang kompatibel untuk menjawab kebutuhan pada era perubahan peradaban (kontekstualisasi PAK). Terlebih, di era perkembangan sains dan teknologi saat ini yang begitu cepat, menjadikan pendidikan menjadi pusat perhatian termasuk PAK itu sendiri. Seymour mengingatkan tentang cara agama Kristen menghadapi masa depan. ${ }^{4}$ PAK sebagai basis ilmu harus mampu sejajar dengan ilmu-ilmu lain yang menunjukkan kemanfaatan nyata bagi perkembangan kemanusiaan. Sesungguhnya keberadaan ilmu sebagai hasil dari kegiatan logika merupakan cahaya bagi perkembangan peradaban manusia dimana ia mendapati dirinya, memahami eksistensinya, merefleksi hidupnya menjadi lebih baik. Manusia sebagai mahluk yang paradox, memaksa ia untuk berenung, bertanya, lalu mencari-cari jawaban dari berbagai aspek dan akhirnya ia menjadi ciptaan yang mampu menemukan sinar kebenaran dalam hidupnya. Untuk itu PAK harus diseret keranah publik untuk melihat dan dilihat apa dan bagaimana dan juga sudah sejauh mana praktik dan peran PAK selama ini terhadap perkembangan kemanusiaan dalam konteks keIndonesiaan. Sebab pada hakikatnya, PAK tidak benar-benar menjadi basis keilmuan pendidikan namun lebih kearah pelanggengan doctrinal aliran gereja tertentu. Hal ini terlihat jelas dengan menjamurkan prodi PAK pada STT-STT dengan pendekatan aliran tertentu yang pada akhirnya akan menghilangkan keuniversalan ilmu PAK itu sendiri. Padahal secara fundamental kita menyadari bahwa pendidikan merupakan persoalan yang melekat secara hakiki di dalam diri manusia. Bisa dibayangkan bagaimana nasib ilmu PAK lewat lulusan sarjana PAK dengan pendekatan model seperti di atas tersebut. Harus disadari bahwa pendidikan menyebar di berbagai aspek kehidupan masyarakat artinya, dimanapun manusia bersosialisasi, berinteraksi dan bereksistensi ada pendidikan di sana sehinga tujuan pendidikan adalah tujuan manusia itu sendiri. Jangan sampai ilmu PAK hilang ditangan teologi walau PAK memiliki landasan teologis. PAK tidak boleh dimonopoli oleh doktrin tertentu, namun ia harus tetap netral dan bersifat universal secara filosofis.

Pengaitan antara filsafat dengan agama dibutuhkan karena keduanya merupakan pedoman dan sumber tata perilaku moral yang dipakai oleh masyarakat pada umumnya. Untuk itulah landasan filsafat perlu hadir sebagai bahan bakar bagi PAK sebagai ilmu. Filsafat merupakan metode untuk berfikir secara sistematis dan kritis. Kattsoff menggambarkan secara rinci bahwa filsafat tidak memberi petunjuk-petunjuk atau melukiskan tehnik-tehnik baru untuk membuat sesuatu seperti membuat bom atom,

${ }^{4}$ Seymour, Memetakan Pendidikan Kristiani: Pendekatan-Pendekatan Menuju Pembelajaran Jemaat (Jakarta: BPK Gunung Mulia, 2018), 10. 
namun filsafat akan membawa manusia memahami dan pemahaman itu menuntunnya pada tindakan yang lebih pasti. Filsafat tidak membuat roti, tetapi filsafat menyiapkan alat memasaknya, menyisihkan setiap noda pada adonan, menambahkan jumlah bumbu dengan ukuran yang pas dan mengangkat adonan dari tungku pada waktunya. ${ }^{5}$ Keberadaan filsafat bertujuan mencari hakikat segala sesuatu sedalam dan seluas mungkin sehingga menemukan kebenaran yang hakiki dan disusun secara sistematik. Sistematika filsafat terbagi dalam beberapa aspek yaitu hakikat sesuatu, nilai dan pengetahuan. Berkaitan dengan hal ini, apa hakikat filsafat PAK? Artikel ini akan mengurai landasan filsafat ilmu PAK dan praksisnya bagi Agama Kristen masa kini yang ditinjau dari sudut pandang ontologis, epistemologis dan aksiologis untuk menemukan kembali batasan dari pengertian PAK yang sesungguhnya.

\section{Metode Penelitian}

Metodologi dalam penelitian ini adalah pendekatan kajian pustaka. Kajian pustaka yang dimaksud dari berbagai tulisan baik buku, jurnal serta literatur-literatur lainnya yang terkait dengan pendidikan agama kristen, landasan ontologis, epistemologi dan aksiologi. Pada tahap awal, akan dipaparkan temuan-temuan kepustakaan yang membangun konsep dan pemahaman terkait dengan definisi pendidikan agama kristen, landasan ontologis, epistemologis dan aksiologis pendidikan agama Kristen. Hasil dari kajian tersebut dipaparkan secara deskriptif sistematis sesuai dengan pengetahuan yang diperoleh dari berbagai literatur. Analisis terhadap pokok pembahasan tersebut, ditelaah dengan merefleksikan temuan literatur dengan implikasi pada masa kini. Kesimpulan diperoleh dari kajian analisis terhadap teori-teori yang dipakai.

\section{Hasil dan Pembahasan}

\section{Ontologi Pendidikan Agama Kristen}

Ontologi merupakan pokok yang mempertanyakan hakikat segala sesuatu yang ada secara hakiki. Ontologi berasal dari bahasa Yunani, yaitu ontos yang berarti ada, dan logos yang berarti ilmu. Ontologi mengkaji sesuai yang ada, sepanjang sesuatu itu ada. Stefanus menjelaskan bahwa ontologi merupakan salah satu kajian kefilsafatan yang membahas keberadaan sesuatu yang bersifat konkret. ${ }^{6}$ Jika hal ini dikaitkan dengan ontologi pendidikan, maka akan membicarakan persoalan tentang keberadaan pendidikan. Secara ontologis pendidikan selalu berada pada hubungan dengan eksistensi kehidupan manusia. Sedangkan eksistensi manusia ditentukan oleh asal usul serta arah yang akan dituju. Jadi, secara ontologis pendidikan berarti pendidikan dalam hubungannya dengan asal mula, eksistensi, dan tujuan serta masa depan. Karenanya, pendidikan tak pernah ada jika manusia tidak ada. Namun, bagaimana halnya jika

\footnotetext{
${ }^{5}$ Louis O. Kattsoff, Pengantar Filsafat (Yogyakarta: Tiara Wacana, 2004), 3.

6 Stefanus Supriyanto, Filsafat Ilmu (Surabaya: Prestasi Pustaka, 2013), 30.
} 
manusia tanpa pendidikan? Apakah mungkin? Eksistensi pelita tanpa cahaya tidaklah berarti. Demikianlah halnya antara manusia dan pendidikan.

Jika pendidikan adalah pendidikan kehidupan, bagaimana halnya dengan ontologi PAK. Ontologi mengajukan pertanyaan tentang keberadaan dan kehidupan. Artinya, secara ontologis PAK juga harus mengacu kepada keberadaan dan kehidupan dimana PAK tidak hanya ada namun juga harus memberi dampak bagi kehidupan. Komunitas kristiani tidak saja hanya sekedar sadar tentang soal-soal iman Kristen yang terdapat pada teks kitab suci namun harus mencapai dimensi dimana iman itu benar-benar memberikan manfaat yang menghidupkan kehidupan manusia seperti yang didengungkan oleh Paulo Freire bahwa praktek pendidikan tidak boleh dibatasi pada pembacaan kata, pembacaan teks saja tetapi selalu percaya bahwa praktek pendidikan juga meliputi pembacaan konteks dan pembacaan dunia"7 Hal ini dikarenakan, seperti pada perumpamaan antara pelita dan cahaya yang pada esensialnya pelita merupakan suluh, namun jika pelita tanpa cahaya, maka ia tidak lagi menghidupi esensinya. Ia mati dan tak berguna tanpa cahaya. Demikianlah halnya pendidikan tanpa mamfaat. Bagaimana PAK yang berbasis pada Alkitab sebagai sumber utama PAK mampu memberikan manfaat. Para pendidik Kristen harus menegakkkan otoritas Alkitab serta memberikan pemahaman yang benar serta Alkitabiah sebab hal itu akan berdampak pada tindakan praktis. Seperti yang diutarakan oleh Darmawan bahwa memahami Firman Tuhan dengan cara yang tidak tepat, dapat menghasilkan refleksi praktis yang tidak benar. ${ }^{8}$

Orang Kristen sepakat bahwa Firman Allah sebagai sumber cahaya bagi kehidupan manusia, namun jika Firman Allah itu hanya dipahami sebagai teks, sebagai hafalan, sebagai doktrinal maka ia sia-sia. Mazmur 119:105 menyiratkan bahwa Tuhan adalah cahaya. Namun yang menjadi titik fokus utamanya adalah bagaimana menjadikan teks Alkitab itu menjadi pelita yang menyinari dan memberikan kehidupan? mau tidak mau secara ontologis PAK harus terhindar dari hanya sekedar konsep-konsep doktrinal tapi lebih mengarah kepada pengkontekstualan teks tersebut sebagai amunisi yang membangkitkan kesadaran utuh tentang realitasnya dan realitas sosial yang lebih luas pada masyarakat yang majemuk baik di Indonesia maupun secara global.

Pada titik inilah pentingnya peran serta tujuan dari pendidikan sebagai pelita yang menyala itu. Pazmino mengemukakan tentang hakikat PAK secara ontologis yang menjelaskan tentang keberadaan dan kehidupan manusia di dunia yang dihubungkan dengan Allah sang pencipta dengan mengutip Kis 17: 28 dimana Paulus berkata dengan tegas bahwa di dalam Yesus Kristus manusia hidup, manusia bergerak dan manusia

\footnotetext{
7 Paulo Freire, Pedagogi Hati (Yogyakarta: Kanisius, 2016), 50.

8 I Putu Ayub Darmawan, Katarina, "Implikasi Alkitab Dalam Formasi Rohani Pada Era Reformasi Gereja," Jurnal Teologi Dan Pelayanan Kristiani Epigraphe 3 (2019): 81-93, http://stttorsina.ac.id/jurnal/index.php/epigraphe/article/view/85.
} 
ada. ${ }^{9}$ Cara pandang Alkitabiah ini menyatakan bahwa keberadaan Allah adalah yang utama, dimana keberadaan manusia bersifat sekunder karena kita berasal dari Dia dan tujuan keberadaan kita adalah memuliakan Allah dan menikmati Dia selamanya. Tuhan yang adalah Maha Kasih dan Maha Adil tidak akan menyerahkan manusia terus terpuruk maka hal ini harus nampak dalam usaha PAK secara ontologis. Dalam keadaan tertentu manusia diperhadapkan dengan situasi yang sulit seperti tragedi virus Corona yang melanda berbagai negara. Hal ini menggiring manusia untuk mempertanyakan kehadiran Allah dan orang Kristen yang tidak memiliki pondasi pemahaman yang kuat akan otoritas Allah, maka ia akan mudah tergiring dengan pandangan Atheisme yang menyangkali keberadaan Allah. ${ }^{10}$

Untuk itu, PAK harus mewujudnyatakan kehadiran Allah melalui setiap aspek dan komponen yang ada dalam pendidikan itu sendiri dengan menuntun serta membawa umat kepada tujuannya masing-masing sesuai dengan kapasitas dan kapabilitasnya. Orang Kristen akan memenuhi tujuan ini dengan cara terlibat secara aktif dalam dunia, tetapi tidak berasal dari dunia ini dan ini semua dimungkinkan dengan karya penebusan Allah. Dengan demikian pelaku-pelaku PAK haruslah mereka-mereka yang telah terubahkan, manusia-manusia yang menyakini akan otoritas Allah dan Alkitab, manusiamanusia yang terampil, manusia-manusia yang memiliki hati sebab PAK sebagai ilmu menyangkut tujuan kehidupan manusia di dalam Kristus dimana kita hidup, kita bergerak, kita ada. Praktik PAK harus memberikan pedoman yang kuat ke arah perjalanan hidup manusia supaya ia mampu ber-ada dan ber-eksistensi sesuai dengan hakikatnya di dalam Allah Tritunggal.

\section{Praksis PAK secara Ontologis}

Secara ontologis diyakini bahwa penyebab keberadaan manusia karena dicipta oleh Allah dan Ia telah menempatkan manusia di dunia seperti yang diuraikan oleh Rasul Paulus bahwa di dalam Dia, manusia hidup, bergerak dan ada. ${ }^{11}$ Hal ini menyiratkan kepada manusia untuk terlibat aktif dalam dunia karena keberadaan manusia sungguhsungguh ada di dunia secara ontologis dan keterlibatan manusia secara aktif kepada Allah sebagai mahluk ciptaanNya. Sebagai mahluk Ilahi orang Kristen hadir di dunia sebagai orang buangan dan musafir. Namun, sebagai bagian dari anggota kerajaan Allah yang menjalani hidup di dunia sebagai praksis PAK, maka orang-orang Kristen harus mengalami pembaharuan kehidupan dalam rangka menggenapi rencana Allah (Filipi 2: 12-13), sebagai ciptaan yang baru orang Kristen harus menjadi duta Allah di dunia yang mengemban misi pembawa berita pendamaian (2 Kor 5: 17-21), dan orang-orang

${ }_{9}^{9}$ Pazmino, Fondasi Pendidikan Kristen, 124.

10 Enggar Objantoro, I Putu Ayub Darmawan, "Signifikansi Ineransi Alkitab Bagi Pendidikan Kristen," Jurnal Teologi Sola Scriptura $1 \quad$ No. $1 \quad$ (2020): 36-52, http://journal.sttjohanescalvin.ac.id/index.php/Scriptura/article/view/34.

11 Pazmino, Fondasi Pendidikan Kristen. 
Kristen setiap hari harus dipenuhi oleh Roh Kudus untuk mencapai tujuan Allah. Sebagai mahluk insani dalam praksis PAK maka orang-orang Kristen memiliki tanggung jawab untuk memelihara bumi yang dicipta oleh Allah sebagai tempat manusia hidup dan menjalani kehidupan dan juga sebagai sumber kehidupan manusia secara insani.

Mazmur 24: 1-2 menyiratkan bahwa Tuhan yang empunya bumi serta segala isinya. Untuk itu, berkaitan dengan pendidikan agama Kristen maka orang-orang Kristen harus ingat bahwa bumi yang disediakan oleh Allah ini harus dijaga yang artinya orangorang Kristen harus peka terhadap isu-isu kosmologis yang berimplikasi penting bagi pendidikan Kristen. Supaya manusia tidak terus terpuruk dan mengalami bencana dalam kehidupannya di dunia, maka pendidikan agama Kristen harus mengajarkan untuk menjaga dan merawat bumi sebagai ekologi kerajaan Allah.

\section{Epistemologi Pendidikan Agama Kristen}

Epistemologi merupakan dasar-dasar dan batas-batas pengetahuan yang dalam bahasa Yunani disebut episteme yang berarti pengetahuan dan logia yang berarti ilmu. ${ }^{12}$ Objek kajian epistemologi adalah mempertanyakan bagaimana pengetahuan itu datang, bagaimana kita mengetahuinya, bagaimana kita membedakan dengan lainnya. ${ }^{13}$ Epistemologi mempelajari tentang sifat, sumber dan validitas dari pengetahuan itu sendiri. Secara umum dapat disimpulkan bahwa epistemologi adalah pengetahuan tentang pengetahuan yang menyandarkan dirinya pada bagaimana manusia memperoleh dan menangkap pengetahuan dan setelah memperoleh pengetahuan, bagaimana manusia memverifikasi pengetahuan tersebut sehingga pengetahuan itu menjadi pengetahuan yang benar. Untuk menjawab bagaimana manusia memperoleh pengetahuannya, Surajiyo mengatakan bahwa pengetahuan diperoleh manusia melalui akal dan panca indra dengan menggunakan metode. ${ }^{14}$

Sejalan dengan pengertian di atas, maka pra ilmuan dibidang PAK telah membuka kembali pembahasan tentang natur pengetahuan dan validitas dari berbagai metode yang dipakai untuk memperoleh pengetahuan. Hal ini memaksa para pendidik Kristen untuk mempertimbangkan kembali Kitab suci sebagai sumber satu-satunya dari semua upaya yang mereka lakukan untuk memperoleh pengetahuan. Sebelumnya Plato mengemukakan bahwa di luar alam nyata ini terdapat dunia 'ide'. Setiap benda yang ada, gagasan aslinya yang abadi ada dalam dunia 'ide'. Artinya setiap benda yang dikenal hanya bayang-bayang dari gagasan asli tersebut. Melalui pendidikan, menurut Plato manusia dibimbing "menilik" melalui pikiran tentang inti abadi dari benda-benda yang

12 Amsal Bakhtiar, Filsafat Ilmu (Jakarta: Rajawali Pers, 2013), 148.

13 Inu Kencana Syafii, Pengantar Filsafat (Bandung: Refika Aditama, 2004), 35.

14 Surajiyo, Ilmu Filsafat (Jakarta: Bumi Aksara, 2008), 53. 
ada di dunia. ${ }^{15}$ Artinya bahwa natur pengetahuan manusia ada pada dunia gagasan atau ide dan metode untuk memperoleh pengetahuan adalah melalui mengingat dan masuk ke dalam dunia ide atau gagasan tersebut. Pernyataan Plato ini bertentangan dengan pendapat Aristoteles dimana ia menitikberatkan pada pentingnya pancaindera manusia. Hal ini ia amati melalui kecenderungan anak-anak kecil untuk menjamah benda-benda, mencium bunga, mengobservasi dunia sekelilingnya, mendengar suara sanak saudaranya, meresapi makna dan seterusnya. ${ }^{16}$ Artinya natur pengetahuan manusia menurut Aristoteles adalah pengalaman dan cara memperoleh pengetahuan adalah dengan menggunakan panca indera. Dalam dunia kontemporer sebagai tantangan masa kini berasal dari pihak saintisisme yang mengatakan bahwa penelitian ilmiah adalah satu-satunya cara mengetahui hal yang bisa diandalkan. Saintisisme yang dikontraskan dari ilmu pengetahuan menyangkal bahwa kebenaran bisa diperoleh lewat penyataan iman Kristen dan berasumsi bahwa pemikiran yang didasarkan pada penelitian ilmiah merupakan cara satu-satunya untuk memperoleh pengetahuan.

Bagaimana natur pengetahuan menurut pandangan Alkitab? menurut Kolose 2: 223 jelas diungkapkan bahwa seluruh kebenaran adalah kebenaran Allah, karena Dia adalah sumber segala pengetahuan hikmat dan pengertian. Pandangan Alkitab terhadap pengetahuan bersifat holistik dalam arti melibatkan pengetahuan dalam arti kognitif sekaligus perasaan dan tindakan. Pengetahuan mencakup dimensi fisik yang menghasilkan komitmen pribadi dan tujuan untuk mengenal seseorang atau mengetahui sesuatu. Parker Palmer dalam usahanya untuk menemukan epistemologi yang Alkitabiah, ia menyatakan bahwa pengetahuan sebagaimana yang dimengerti dalam konteks masyarakat harus dikaitkan dengan minat dan hasrat manusia. Dalam analisisnya Palmer mengatakan bahwa pengetahuan dapat diikatkan pada tiga macam minat atau hasrat manusia yakni kendali, keingintahuan dan belas kasihan. Pengetahuan yang diperoleh melalui studi empiris dan analitis biasanya bertujuan untuk mengendalikan sejumlah informasi tertentu. Pengetahuan yang diperoleh melalui studi spekulatif, historis dan hermeneutik biasanya bertujuan untuk memperoleh pengetahuan sebagai tujuan untuk memuaskan keingintahuannya. Pengetahuan yang membebaskan dijelaskan dalam 1 Kor 8: 1-3 yaitu pengetahuan yang tidak membuat orang menjadi sombong melainkan membuat orang mengasihi Allah dan sesama. Pengetahuan jenis ini diasosiasikan dengan minat untuk berbelaskasihan atau untuk mengasihi. ${ }^{17}$

Masalah yang dihadapi oleh pendidik Kristen adalah bagaimana mempertahankan kebenaran dalam suatu tekanan untuk membedakan manakah kebenaran yang diperoleh lewat penelitian dari berbagai disiplin ilmu dan manakah kebenaran yang

15 Robert R. Boehlke, Sejarah Perkembangan Pikiran Dan Praktek PAK Dari Plato Sampai Ignasius Loyola (Jakarta: BPK Gunung Mulia, 2018), 6.

16 Ibid, 11.

${ }^{17}$ Pazmino, Fondasi Pendidikan Kristen, 129. 
dinyatakan Alkitab. Dalam kaitan dengan masalah ini, Geroge Knigth memberikan enam hasil observasi epistemologisnya: pertama, perspektif Alkitab menyatakan bahwa seluruh kebenaran adalah kebenaran Allah dan itu berarti mengeliminasi adanya perbedaan antara kebenaran sekuler dan rohani. Kedua, kebenaran dari penyataan kristiani adalah benar adanya sesuai dengan apa yang ada pada alam semesta, sehingga orang Kristen bisa mengejar kebenaran tanpa merasa takut menghadapi terjadinya kontradiksi yang bersifat ultimat. Ketiga, kekuatan jahat berusaha merendahkan Alkitab, membelokkan pemikiran manusia dan mengarahkan manusia untuk bergantung pada ketidakmampuan diri sendiri yang sudah jatuh dalam dosa dalam upayanya mengejar kebenaran. Keempat, Alkitab tidak hanya berisi kebenaran abstrak, tetapi juga kebenaran yang berkaitan dengan kehidupan. Karena itu, mempunyai pengetahuan dalam pengertian Alkitab adalah menerapkan pengetahuan yang sudah didapat dalam kehidupan sehari-hari. Kelima, berbagai sumber pengetahuan tersedia bagi orang Kristen (penyataan khusus dari Alkitab, penyataan umum dari alam semesta dan pikiran) yang bersifat saling melengkapi dan seharusnya dipergunakan menurut pola yang Alkitabiah. Keenam, dengan adanya keutuhan kebenaran, penerimaan terhadap epistemologi kristiani tidak bisa dipisahkan dari metafisik kristiani. ${ }^{18}$

Dalam hal ini, perspektif kristiani dalam hal iman memberikan sebuah alternatif dalam memperoleh pengetahuan yang meluas, tetapi tidak bertentangan dengan kebenaran ilmu pengetahuan karena seluruh kebenaran adalah kebenaran Allah. Orang Kristen bebas mengeksplorasi ide-ide penting dalam ilmu pengetahuan baik yang ditemukan melalui pemikiran maupun melalui observasi empiris terhadap dunia sebagai penyataan umum dari Allah. Namun orang Kristen harus sadar akan potensi dari kekuatan-kekuatan jahat yang berusaha mengagungkan ilmu pengetahuan dengan cara yang tidak tepat. Sebuah epistemologi Kristen bergantung pada metafisik Kristen dan secara khusus kosmologi Kristen yang melihat dunia ini sebagai ciptaan Allah dan sebab itu harus tunduk kepada Allah dalam segala variasi dan keutuhannya.

\section{Praksis Epistemologis Pendidikan Agama Kristen}

Wilayah dan kompetensi epistemologi PAK yaitu mengklarifikasi bebagai persoalan seperti apa sumber rujukan pengetahuan PAK? Bagaimana cara memperoleh pengetahuan PAK tersebut? Bagaimana validitas pengetahuan PAK tersebut dapat dipertanggung jawabakan? Khoe Yao Thung merincikan secara jelas bahwa landasan epistemologis PAK adalah Allah Tritunggal di dalam Yesus Kristus dan Alkitab sebagai perwujudan wahyu Allah. ${ }^{19}$ Iman Kristen mengajarkan bahwa dunia benar-benar ada serta berwujud sebagai pengetahuan yang real dan Yesus kristus sebagai poros

\footnotetext{
18 Ibid., 130.

${ }^{19}$ Khoe Yao Tung, Filsafat Pendidikan Kristen (Yogyakarta: ANDI, 2013), 9-10.
} 
pengetahuan. Kehadiran Yesus dalam sejarah manusia untuk menjelaskan "Dia yang Ilahi, yang Misteri dan yang ter-tinggi."20 Artinya tidak seorang pun yang tahu akan keber-Ada-an Allah (Bapa). Allah ada dan Ia ada dalam keber-Ada-an-Nya (being). Yesus yang adalah Putera Tunggal Allah keluar dari Allah dan Dialah yang menyaksikan keberAda-an Allah (Bapa). Diri Allah. Kristus adalah sumber hikmat karena seluruh kepenuhan dan hikmat Allah berdiam di dalam diriNya dan Alkitab sebagai sumber rujukan tekstual untuk menggali pengetahuan. Pengetahuan melalui usaha PAK harus membuat manusia memiliki kesadaran akan diri dan fungsinya di tengah dunia. Melalui kesadarannya manusia mampu berefleksi dan merealisasikan diri menuju dirinya yang sejati sebagaimana yang diteladankan oleh Yesus Kristus.

Secara tektual maka Alkitab adalah sumber epistemologi PAK. Alkitab harus menjadi bahan rujukan dalam PAK. Gaebelein, seperti dikutip oleh Gangel berkata bahwa: pendidik Kristen seyogianya tetap yakin dan percaya diri dengan menempatkan Alkitab sebagai yang tertinggi dan pusat kurikulum dalam pendidikan dan tidak terlena dengan kecanggihan dunia pendidikan. ${ }^{21}$ Iris Cully juga menandaskan hal senada bahwa Alkitab adalah Firman Allah yang dinamis bukan statis sehingga, ketika mengajarkannya Alkitab harus dihubungkan dengan kehidupan melalui teladan hidup, kematian dan kebangkitan Yesus Kristus. ${ }^{22}$ Jadi dapat disimpulkan bahwa Alkitab dan Yesus Kristus Tuhan adalah sumber epistemologi PAK. Pendidik Kristen dapat membuktikannya dengan menggunakan panca indera dan kesaksian dimana sudah banyak kesaksian yang diberikan mengenai hal ini secara turun temurun. Tidak ada kebenaran di luar kerangka metafisika Allah. Semua kebenaran yang ada di dunia ini semuanya tertulis dalam Alkitab. Akan tetapi Alkitab hanya memberikan kebenaran secara garis besar, tidak menjelaskan suatu hal secara keseluruhan. Contoh udara, Allah yang menciptakan udara tapi tidak dijelaskan bahwa udara mengandung nitrogen, oksigen dan argon.

Manusia merupakan objek pendidikan sehingga belajar tentang hakikat manusia akan menyempurnakan pendidikan demikian sebaliknya. Kattsoff berkata "perbudakan akali jauh lebih memilukan daripada perbudakan ragawi sebab perbudakan ragawi hanya sebatas tubuh. Namun, jika seseorang diperbudak secara akali, maka apapun akan dilakukan untuk menjadikan akal pikirannya aus sehingga akal pikiran tersebut tidak lagi dapat bekerja; suatu kisah yang jauh lebih menyedihkan. Konteks ini menunjukkan dengan tepat bahwa makna kebebasan akali hanya bisa diperoleh melalui pendidikan. Pendidikan dalam kerangka berpikir kritis menjadi sangat penting secara fundamental bagi manusia. Manusia seharusnya secara bersama harus melihat lebih dalam bagaimana sebenarnya PAK "menafsirkan manusia", bukan hanya bercerita bagaimana mengubah manusia. Epistemologi PAK tidak boleh terjebak pada romantisisme apalagi

20 Tom Jakobs, Paham Allah; Dalam Filsafat, Agama-Agama dan Teologi (Yogyakarta: Kanisius, 2004), 160

${ }^{21}$ Kenneth O. Gangel, Membina Pemimpin Pendidikan Kristen (Malang: Gandum Mas, 1998), 40.

${ }^{22}$ Iris V. Cully, Dinamika Pendidikan Kristen (Jakarta: BPK Gunung Mulia, 1995), 36. 
meromantisasi dimana getol menafsir ketimbang memikir, bersemangat memperluas makna-makna tanpa mampu melihat fakta.

\section{Aksiologi Pendidikan Agama Kristen}

Jangan sampai seseorang hanya cerdas mengajar orang lain, namun terlalu bodoh untuk mengajar diri sendiri. Kalimat ini sebagai kalimat pengantar yang fundamental filosofis sebagai landasan untuk mendudukkan aksiologi PAK sebab manusia diproyeksikan oleh manusia lain melalui perbuatannya. Aksiologi adalah ilmu yang memperlajari tentang nilai yaitu nilai etika dan estetika. Nilai etika berkaitan dengan moralitas dan nilai dalam estetika berkaitan dengan apa yang baik dan buruk, layak dan tidak layak. Menurut Suriasumantri aksiologi adalah teori nilai yang berkaitan dengan kegunaan dari pengetahuan yang diperoleh. ${ }^{23}$ Dengan demikian peran aksiologi akan dan harus lebih mengedepankan dalam kemanfaatan bagi kepentingan manusia dan kemanusiaan.

Aksiologi ilmu tidak bisa dilepaskan dari moralitas dimana secara moral, ilmu harus mendatangkan manfaat bagi manusia tanpa mendistorsi identitas kemanusian. Etika Kristen berurusan dengan realitas dosa dan panggilan kristiani untuk melayani dan berkorban di dunia. Estetika kristiani didasarkan pada fakta bahwa Allah menciptakan dunia itu indah dan ini mengimplikasikan suatu tanggungjawab pribadi baik untuk menghargai maupun untuk menciptakan keindahan. Ada empat implikasi aksiologis bagi para pendidik Kristen di antaranya: ${ }^{24}$ Pertama, pendidik Kristen harus sadar akan nilai-nilai yang mendasari usaha mereka dalam pengajaran, pelayanan dan kehidupan dimana hal ini diasumsikan pada komitmen pribadi terhadap nilai-nilai yang dianutnya. Kedua, pendidik Kristen harus menterjemahkan nilai-nilai mereka ke dalam tujuan umum dan khusus secara aktual sebagai pemandu dalam praktik pendidikan mereka dimana nilai-nilai itu disintesiskan dan diinternalisasikan ke dalam seluruh upaya pendidikan, sehingga orang dapat didorong untuk bertindak secara konsisten selaras dengan nilai-nilai yang dinyatakan. Ketiga, nilai-nilai itu harus diaplikasikan dalam konteks komunal dan institusional karena kita hidup dalam dunia yang komunal dan institusional sehingga nilai-nilai itu tidak dianggap sebagai sesuatu yang bersifat pribadi sekali (kedamaian saya, sukacita saya, identitas diri saya, harga diri saya, kesehatan saya dan saya-saya yang lainnya). Keempat, pendidik Kristen harus sadar akan adanya kebutuhan konstan untuk memperbaharui nilai-nilai mereka.

\section{Praksis Aksiologis Pendidikan Agama Kristen}

Pendidikan merupakan suluh yang harus terus menyala untuk menerangi dan menuntun manusia. Dan sebagai pelaku PAK ia harus terus diubahkan oleh Roh Kudus

23 Jujun S. Suriasumantri, Filsafat Ilmu: Sebuah Pengantar Populer (Jakarta: Pustaka Sinar Harapan, 1998), 34-35.

24 Pazmino, Fondasi Pendidikan Kristen, 136-137. 
melalui firman Allah. ${ }^{25}$ Pembahasan tentang aksiologis PAK telah membuat pendidik Kristen memahami pentingnya peran dari nilai kristiani dalam pengambilan keputusan untuk merumuskan tujuan umum dan khusus pendidikan agama Kristen. Vieth mengajukan tujuh rumusan aksiologis dari tujuan PAK yaitu: ${ }^{26}$ pertama, berusaha menginsyafkan akan Tuhan sebagai suatu kenyataan dalam pengalaman manusia, dan suatu perasaan akan hubungan personal dengan Tuhan dalam Yesus Kristus. Kedua, berusaha mengembangkan pengertian dan penghargaan terhadap kepribadian, kehidupan dan pengajaran Yesus, sehingga membawa orang-orang mengalami Dia sebagai Tuhan dan Juruselamat dan mengikuti Dia dengan setia dan taat dalam hidup serta tindakan sehari-hari. Ketiga, berusaha mengembangkan karakter yang makin serupa dengan Kristus secara progresif dan kontinu lewat pekerjaan Roh Kudus. Keempat, berusaha mengembangkan kemampuan dan kecenderungan untuk berpartipasi dan merespon dampak Injil secara sosial dan spiritual, dengan cara menjalani hidup di dunia ini, tetapi tidak hidup menurut jalan yang berlaku di dunia. Kelima, berusaha mengembangkan kemampuan kemampuan dan kecenderungan untuk berpartisipasi secara bertanggungjawab di dalam keluarga kristen. Keenam, berusaha mendorong dalam mengembangkan cara pandang kristiani yang dikontekstualisasikan dalam kehidupan setiap orang. Ketujuh, berusaha mendidik orang Kristen di bawah bimbingan Allah sebagaimana telah tercatat dalam Alkitab dengan baik sekali sehingga catatan Alkitab ini akan memberikan bimbingan yang otoritatif bagi perjalanan iman dan kehidupan. Ketujuh rumusan tersebut merupakan landasan filosofis dalam merumuskan praksis aksiologis PAK yang berimplikasi bagi agama Kristen masa kini.

\section{Pembahasan Penelitian}

Penamaan PAK secara umum sering dipahami seolah-olah hanya bersangkut paut dengan persoalan iman Kristen. Apakah memang demikian bahwa sesungguhnya PAK itu hanya melulu soal iman Kristen? jika tidak cerdas dan cermat untuk mendudukkan posisinya, maka pendidikan model seperti ini sangat mudah terpenjara pada PAK yang egois doktrinal dimana seolah-olah PAK hanya sekedar mengurusi dirinya sendiri (selfcentered) dan hanya soal agama Kristen itu sendiri. Akibatnya, tidak sedikit para pengikut iman Kristen tidak peka terhadap isu-isu trans-nasional dan malah abai terhadap persoalan-persoalan real yang dihadapi seperti kemiskinan, ${ }^{27}$ kesenjangan pembangunan, gizi buruk. ${ }^{28}$ Dengan kata lain, PAK seolah-olah hanya diajarkan berdoa dan berdoa dengan mengedepankan keyakinan-keyakinan yang hiperbolaik dan pada akhirnya seolah-olah berpasrah diri. Pembangunan gedung gereja marak dan megah

25 Tety \& Soeparwata Wiraatmadja, "PRINSIP-PRINSIP FILSAFAT PENDIDIKAN KRISTEN,"

Evangelikal: Jurnal Teologi Injili Dan Pembinaan Warga Jemaat 1 No.1 (2017), https://journal.sttsimpson.ac.id/index.php/EJTI/article/view/56.

26 Ibid., 144-145.

27 PERPRES 63 Tahun 2020 penetapan daerah tertinggal

${ }^{28} \mathrm{https} / / /$ mediaindonesia.com/read/detail/278490-ntt-terancam-kehilangan-generasi-akibat-stunting 
namun pengikutnya kurang gizi dan mengalami stunting. Sekolah-sekolah tinggi teologia marak berdiri namun tidak menunjukkan dampak yang berarti selain daripada mengagung-agungkan paham teologisnya. Seolah-olah "bermegah" dan menganggap bahwa PAK itu ada di negeri antah berantah yang mengharapkan langit dan bumi baru. Tidak apa-apa miskin di bumi, tidak terdidik dan lain sebagainya, sebab pengharapan ada disorga. Tidak mengherankan kritik Marx terhadap agama sebagai candu mendapat legitimasi karena agama tidak mampu menjadi jalan perjuangan emansipasi manusia tetapi justru sebagai alat pelayan kepentingan-kepentingan kekuasaan.

Secara ontologis penulis meyakini dua aspek keberadaan manusia secara eksistensial yaitu aspek teologis dan aspek sosial. Untuk itu keberadaan ilmu PAK sebagai praksis harus hadir dan memberikan warna yang sentral terhadap eksistensi manusia dimana PAK memberikan arah yang cerah terhadap hakikat keberadaan manusia dan tujuan dari kehidupan manusia. PAK harus memberikan kesadaran sosial bahwa keberadaan umat Kristen di dalam dunia nyata memiliki tanggungjawab sosial sebagai bagian dari tanggung jawab teologisnya. Sering dilupakan bahwa sesungguhnya PAK yang membahas soal-soal iman Kristen, berada pada komunitas sosial berbangsa dan bernegara yang tidak hanya berada pada komunitas kristiani saja namun juga berada pada komunitas agama-agama lain. Sehingga kekristenan seolah-olah loyo tak berdaya dihadapan kaum ekstrimisme, terorisme, politik identitas dan seraya berharap mujizat dan mujizat. Pada tatanan ini PAK sebagai ilmu harus menunjukkan jatidirinya, apakah menjadi komunitas yang mengeksklusifkan dirinya atau dia membuka ruang dimana terlihat kemanfaatan dari ilmu pendidikan agama kristen itu bagi sesama di luar dirinya seperti pada ungkapan "menjadi garam dan terang". Ini menjadi perenungan bersama para pemikir-pemikir Kristen dimana pendidikan agama Kristen diperkenalkan sebagai ilmu (teori dan praksis), metode (alat dan strategi menerapkan), dan tujuan untuk memberikan edukasi dan mengedukasi masyarakat lain di luar dirinya. Untuk mencapai ini semua, maka perlu menelisik kembali pengertian PAK secara ontologis.

Secara epistemologis, Alkitab sebagai wahyu Allah dan Yesus yang berinkarnasi menjadi manusia merupakan sumber landasan ilmu PAK. Pada pendahuluan sangat jelas digariskan bahwa pendidikan agama kristen bukan hanya sekedar keyakinan-keyakinan yang doktrinal melainkan agama Kristen juga merupakan bagian dari ilmu maka disebut pendidikan agama Kristen. Asumsi penulis, pendidikan agama kristen sebagai ilmu dimana ilmu adalah sebuah tindakan atau upaya yang disengaja secara metodologis yaitu melalui metode dan prosedural yang sistematis untuk mengkajinya. Sehingga dengan cara yang metodologis, agama kristen tidak hanya diposisikan sebatas doktrinal sebagai pandangan hidup namun sebagai ilmu pendidikan; maka PAK menjadi edukasi dan eduaksi untuk meningkatkan kualitas hidup bukan hanya keyakinan namun juga intelektual. Pemahaman pendefinisian PAK seperti ini akan memberikan dampak vital 
bagi komunitas kristiani untuk peningkatan kualitas hidup masyarakat kristen pada arena sosial yang lebih luas dan konkret. Sehingga masyarakat kristiani tidak hanya sekedar saleh, namun juga cerdas. Masyarakat kristiani tidak hanya sekedar hegemoni namun mampu berkompetisi dan memberikan warna tersendiri bagi pembangunan kemanusiaan yaitu memanusiakan manusia dalam istilah biblikal menjadi garam dan terang. Dengan harapan tidak lagi diperhadapkan dengan data-data basis Kristen yang memasygulkan hati. Oleh sebab itu PAK harus hidup dan semakin menghidupkan lewat proses edukasi dan eduaksi sebagai basis ilmu dan setara dengan ilmu-ilmu yang lainnya yaitu memberikan keterampilan hidup yaitu kematangan spritual, sosial dan intelektual. Kematangan inilah yang bisa memberikan dampak yang konkrit bagi komunitas kristiani di arena sosial yang lebih luas dan majemuk.

Kualitas intelektual masyarakat Kristen akan menentukan maju mundurnya komunitas agama Kristen itu sendiri, dan hal ini menjadi tantangan serius bagi ilmu PAK. Menelisik definisi pendidikan agama Kristen oleh para ahli yang terdapat pada buku-buku cetakan PAK yang terdapat di Indonesia, secara epistemologis mereka lebih menekankan pada aspek spiritual dan "melupakan" aspek intelektual. Langeveld menyatakan bahwa pendidikan merupakan kegiatan membimbing setiap insan menuju kepada kedewasaan dan kemandirian. ${ }^{29}$ Menarik untuk dipikirkan kembali, apakah defenisi pendidikan agama Kristen hanya sebatas itu saja atau ada dimensi lain yang terlupakan dalam pendefinisian PAK? jika ditelisik lebih dalam dari defenisi PAK di atas, maka PAK "bukan" untuk mengembangkan intelektualitas manusia namun semata-mata spiritualitas yang sesuai dengan kehendak Allah (menjadi orang saleh). Dengan kata lain, melalui Firman Tuhan yang tertulis inilah, umat dibimbing dalam kebenaran. Untuk itu perlu dibuat garis demarkasi yang tegas yaitu PAK sebagai dogma dan PAK sebagai ilmu. PAK dalam pengertian dogmatis, maka pengertian di atas adalah tepat (menjadi manusia saleh). Namun kalau ditinjau dari PAK sebagai ilmu, maka pengertian di atas kurang tepat. Kalau tidak, maka yang muncul adalah komunitas saleh namun "lugu."

Secara epistemologis, ilmu PAK berfungsi sebagai landasan pengembangan pengetahuan dan potensi intelektual untuk mencapai kematangan intelektual yang berdaya guna bagi kelangsungan hidupnya sehari-hari dengan keahlian khusus, kecakapan dan keterampilan-keterampilan. PAK dimanapun dilaksanakan harus mempersiapkan anak supaya bisa mandiri dan berdikari. Sebab sejatinya usaha pendidikan seperti yang diungkapkan oleh Driyarkara yaitu bertujuan untuk memanusiakan manusia. Ketika seorang anak hadir di dunia, ia diperlengkapi dengan berbagai kemampuan dan kompetensi yang harus diaktualisasikan. Proses aktualisasi inilah disebut pendidikan dan proses ini berlangsung sampai anak mencapai kematangan yang utuh yaitu dimana seorang anak memiliki kecakapan dan mampu

${ }^{29}$ M. J. Langeveld, Pedogogik Teoritis Sistematis, Terj. Simajuntak (Bandung: Jemmars, 1980), 20. 
berefleksi untuk bertindak secara mandiri, bebas dan bertanggungjawab akan hidupnya. Untuk hal ini, maka usaha PAK tidak boleh menjadi antitesa.

Secara aksiologis, ketika PAK mengajarkan bahwa Yesus Kristus sebagai Tuhan yang merupakan sang pendidik agung manusia melalui pengajaran dan pengasuhanNya, apa mamfaat langsung dari pengetahuan tersebut. Di tengah keterasingan hidup manusia akibat dominasi IPTEK yang mengabaikan nilai, filsafat yang didasarkan pada akal ansich sehingga melahirkan pandangan yang menihilkan nilai. Hal ini berdampak buruk pada praksis PAK yang mana perilaku menyimpang semakin nyata-nyata hari ini karena absennya nilai dalam praksis PAK. Atas dasar itu, PAK harus memperkuat praksis pendidikan yang bersumber dari Alkitab sehingga bisa melahirkan konsepkonsep PAK yang berwajah humanistik yang penuh kasih sehingga melahirkan generasi yang dapat mengejawantahkan nilai-nilai yang terkandung dalam Kitab Galatia 4:22-23.

Sudut pandang pendidikan humanis ini memandang manusia sebagai suatu kesatuan yang integralistik yaitu sebagai makhluk hidup ciptaan Tuhan dengan tujuantujuan tertentu yang tidak bertentangan dengan kodrat imago dei dalam dirinya. ${ }^{30}$ Dengan berpedoman pada pendidikan yang dilandasi nilai-nilai kemanusiaan di atas, maka terdapat harapan besar bahwa nilai-nilai pragmatis ilmu pengetahuan dan teknologi, berbagai persoalan yang dilematik serta krisis kemanusiaan lainnya, tidak akan melenyapkan eksistensi dan kepentingan-kepentingan kemanusiaan. Lebih lanjut, dengan nilai PAK, dunia manusia diharapkan akan terhindar dari agresi fundamentalisme, ekstrimisme, terorisme bahkan juga tirani ilmu pengetahuan, sains dan teknologi. Dan pada aspek lainnya yaitu mendorong terciptanya hidup dan kehidupan yang kondusif dan harmonis. Dengan demikian, aksiologi PAK berarti bagaimana konsep dan teori-teori PAK yang bersifat abstrak dapat diaplikasikan melalui aspek habituatif dan augmentatif umat kristiani dalam dunia kenyataan yang sesungguhnya.

\section{Kesimpulan}

Berdasarkan penjelasan di atas, PAK bersumber pada Alkitab yang menuntun setiap orang kepada kebenaran Ilahi menuju rencana Allah melalui teladan Yesus Kristus. Melalui pendidikan, maka agama kristen seharusnya mendorong untuk menyuburkan sisi-sisi terbaik manusia sebagai "hearth in the heartless world." Para pendidik Kristen harus menyadari bahwa antusiasme yang berlebihan yang membabi buta akibat dari kesempitan berpikir dan kesempitan wawasan, krisis identitas sering sekali mereduksi dan mengubur hakikat dari agama Kristen. Gereja dan sekolah yang menjunjung nilainilai PAK harus berhati-hati terhadap kejadian atau situasi yang bertentangan dengan

30 Udau Samuel, Tanuwidjaja Sundoro, "Iman Kristen Dan Kebudayaan," Jurnal Teologi Kontekstual Indonesia 1 No.1 (2020): 1-14, https://journal.sttsimpson.ac.id/index.php/JTKI/article/view/299/pdf. 
yang diharapkan yang kerap tidak disadari itu. Iman yang terkandung dalam agama Kristen bukan hanya perkara perasaan dan hati. Antusiasme perasaan yang berlebihan bisa berdampak keluar, ngawur dan mengerikan, apalagi bila agresi dihayati sebagai kesalehan. Dalam berhadapan dengan berbagai kompleksitas kehidupan dan peradaban kemanusiaan, iman perlu juga dijernihkan dan dimatangkan oleh akal budi untuk itulah perlu landasan filosofis PAK agar hati dan perasaan diasah dan dididik oleh penalaran. PAK bukan sebuah proposisi (dogma) tetapi PAK soal perbuatan. PAK harus menjadi benteng yang kuat dimana harkat dan martabat kemanusiaan, peradaban dan kehidupan dirawat serta dipertahankan. Dengan kata lain berusaha untuk mampu memanusiakan manusia itu sendiri dan membebaskannya dari alienasi peran kemanusiaannya dalam kehidupan.

Saran yang dapat penulis berikan yaitu pada era post-modernisme saat ini yang mengedepankan prinsip relativisme, sudah saatnya PAK yang ada pada lembaga pendidikan berpikir secara kritis dan menempatkan PAK sebagai basis ilmu. PAK jangan terjebak pada indoktrinasi semu, namun ilmu pendidikan agama Kristen harus bebas doktrin dan bersifat universal sebab sesungguhnya ideologi dari pengajaran Yesus Kristus sang Guru Agung adalah kerajaan Allah. Cakupan kerajaan Allah itu bukan hanya ada di luar sana, tetapi tantangannya adalah bagaimana pendidikan agama Kristen melalui umatNya mampu menghadirkan kerajaan Allah di bumi. Untuk itu landasan filsafat pendidikan agama Kristen sebagai basis ilmu didik mendidik harus mampu menjadikan umatNya berdikari dan berefleksi secara ontologis, epistemologis dan aksiologis. Pendidikan agama Kristen sebagai basis ilmu harus mampu menunjukkan kontribusinya terhadap pendasaran iman atau kepercayaan, sebab iman memerlukan dasar yang masuk akal. Beriman berarti perlu menjelaskan mengapa mereka memeluk imannya. Umat beragama membutuhkan sebuah argumen yang kuat melalui pendidikan untuk memperkuat iman bukan hanya sekedar mempercayai.

\section{Referensi}

Amrstrong, Karen. A History of God. New York: Alfred A Knopf Inc, 1993.

Bakhtiar, Amsal. Filsafat Ilmu. Jakarta: Rajawali, 2013.

Boehlke, Robert R. Sejarah Perkembangan Pikiran Dan Praktek PAK Dari Plato Sampai Ignasius Loyola. Jakarta: BPK Gunung Mulia, 2018.

Cully, Iris V. Dinamika Pendidikan Kristen. Jakarta: BPK Gunung Mulia, 1995.

Freire, Paulo. Pedagogi Hati. Yogyakarta: Kanisius, 2016.

Gangel, Kenneth O. Membina Pemimpin Pendidikan Kristen. Malang: Gandum Mas, 1998.

Hutapea, Rinto Hasiholan. "Evaluasi Pembelajaran Pendidikan Agama Kristen Pada Kurikulum 2013N." Jurnal Ilmiah Religiosity Entity Humanity (JIREH). Vol. 1, 2019.

I Putu Ayub Darmawan, EnggarObjantoro. "Signifikansi Ineransi Alkitab Bagi Pendidikan

Kristen." Jurnal Teologi Sola Scriptura 1 No. 1 (2020): 36-52. 
http://journal.sttjohanescalvin.ac.id/index.php/Scriptura/article/view/34.

Jakobs, Tom. Paham Allah; Dalam Filsafat, Agama-Agama Dan Teologi. Yogyakarta: Kanisius, 2004.

Katarina, I Putu Ayub Darmawan. "Implikasi Alkitab Dalam Formasi Rohani Pada Era Reformasi Gereja." Jurnal Teologi Dan Pelayanan Kristiani Epigraphe 3 (2019): 8193. http://stttorsina.ac.id/jurnal/index.php/epigraphe/article/view/85.

Kattsoff, Louis O. Pengantar Filsafat. Yogyakarta: Tiara Wacana, 2004.

Langeveld, M. J. Pedogogik Teoritis Sistematis, Terj.:Simajuntak. Bandung: Jemmars, 1980. Pazmino, Robert W. Fondasi Pendidikan Kristen. Jakarta: BPK Gunung Mulia, 2016.

Seymour, Jack L. Memetakan Pendidikan Kristiani: Pendekatan-Pendekatan Menuju Pembelajaran Jemaat. Jakarta: BPK Gunung Mulia, 2018.

Supriyanto, Stefanus. Filsafat Ilmu. Surabaya: Prestasi Pustaka, 2013.

Surajiyo. Ilmu Filsafat. Jakarta: Bumi Aksara, 2008.

Suriasumantri, Jujun S. Filsafat Ilmu: Sebuah Pengantar Populer. Jakarta: Pustaka Sinar Harapan, 1998.

Syafii, Inu Kencana. Pengantar Filsafat. Bandung: Refika Aditama, 2004.

Tambunan, Elia. "GERAKAN TRANSNASIONAL KRISTEN: WAJAH EKONOMI-POLITIK AGAMA DAN PENDIDIKAN DI INDONESIA" 1, no. 1 (2019): 1-17.

Tanuwidjaja Sundoro, Udau Samuel. "Iman Kristen Dan Kebudayaan.” Jurnal Teologi Kontekstual Indonesia 12 No.1 (2020): 1-14. https://journal.sttsimpson.ac.id/index.php/JTKI/article/view/299/pdf.

Tety \& Soeparwata Wiraatmadja. "PRINSIP-PRINSIP FILSAFAT PENDIDIKAN KRISTEN."

Evangelikal: Jurnal Teologi Injili Dan Pembinaan Warga Jemaat 1 No.1 (2017). https://journal.sttsimpson.ac.id/index.php/EJTI/article/view/56.

Tung, Khoe Yao. Filsafat Pendidikan Kristen. Yogyakarta: ANDI, 2013. 